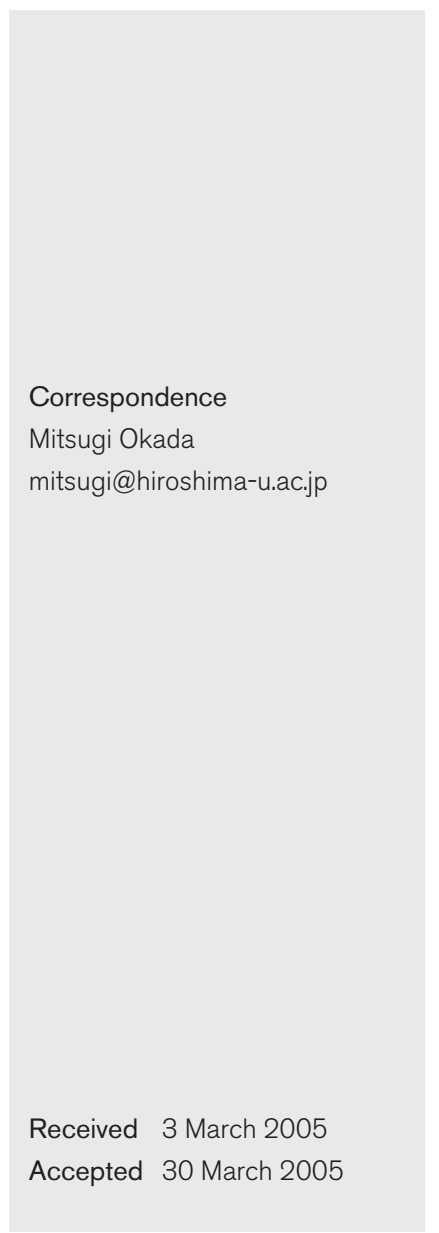

\title{
Longitudinal study of dental caries incidence associated with Streptococcus mutans and Streptococcus sobrinus in pre-school children
}

\author{
Mitsugi Okada, Yoshiko Soda, Fumiko Hayashi, Takako Doi, Junji Suzuki, \\ Kazuo Miura and Katsuyuki Kozai
}

Department of Pediatric Dentistry, Hiroshima University Faculty of Dentistry, Hiroshima, Japan

\begin{abstract}
Streptococcus mutans and Streptococcus sobrinus are known to be associated with the development of dental caries. In this study these bacteria were detected in pre-school children (each with primary dentition, age range $3-5$ years, $n=60$ ) using a PCR method, and then their presence was compared with the incidence of dental caries over a 1-year period. Plaque samples were collected from all erupted tooth sites using a sterile toothbrush. Dental examinations at the beginning of the study (baseline) and after 1 year were also performed to determine decayed, missing, filled teeth (dmft) scores using WHO caries diagnostic criteria. The prevalences of $S$. mutans and $S$. sobrinus across all the subjects were $61 \cdot 7 \%$ and $56 \cdot 6 \%$, respectively; 13 subjects $(21 \cdot 7 \%)$ were positive for S. mutans alone, 10 (16.6\%) were positive for S. sobrinus alone and $24(40.0 \%)$ were positive for both $S$. mutans and S. sobrinus, whereas $13(21.7 \%)$ were negative for both $S$. mutans and S. sobrinus. dmft scores of subjects positive for both S. mutans and S. sobrinus at baseline and after 1 year were significantly higher than of those positive for $S$. mutans alone at the same stages $(P<0.01$ and $P<0.001$, respectively). The caries incremental increase was also significantly greater in those with both bacteria detected $(P<0.05)$. Our results indicate that pre-school children harbouring both $S$. mutans and $S$. sobrinus have a significantly higher incidence of dental caries than those with $S$. mutans alone.
\end{abstract}

\section{INTRODUCTION}

Mutans streptococci (Streptococcus mutans and Streptococcus sobrinus) are considered to be major dental caries aetiologic agents. They are the most common pathogens isolated from human dental plaque and their prevalence has been reported in epidemiological studies (Hamada \& Slade, 1980; Whiley \& Beighton, 1998). S. mutans has been shown to be more prevalent than S. sobrinus in dental plaque samples (Loesche, 1986; Carlsson et al., 1987), while several epidemiological studies have shown that the prevalence of $S$. sobrinus is more closely associated with high caries activity (Fujiwara et al., 1991; Hirose et al., 1993).

In several epidemiological studies, identification of S. mutans and S. sobrinus on selective media such as mitis-salivarius (MS) or MS-bacitracin (MSB) agar has been performed using colonial morphology (Wade et al., 1986; Svanberg \& Krasse, 1990). However, accurate differentiation between S. mutans and S. sobrinus is not easy, and is also timeconsuming and laborious (de Soet et al., 1990). Further, it has been reported that $S$. sobrinus from dental plaque samples is especially difficult to culture directly on MSB selective

Abbreviation: dmft, Decayed, missing, filled teeth. medium (Jordan 1986; de Soet et al., 1990). Thus, it is of great importance to distinguish the presence of these two species separately in children for accurate prediction and effective prevention of dental caries.

Thus far, several methods used for detecting and identifying mutans streptococci have been reported, including direct microscopy, cultivation, enzyme tests, mAbs, ELISAs and species-specific DNA probes. Several investigators have also developed PCR methods and reported them to be more sensitive for detection than conventional culture techniques (Ono et al., 1994; Igarashi et al., 2000), as they have been shown to be able to detect low numbers of bacterial species with a detection limit of as few as $25-100$ cells (Igarashi et al., 1996, 2000), while being quick and relatively simple to perform. Further, PCR assays were found to be suitable for the specific detection and identification of human cariogenic bacteria, such as S. mutans and S. sobrinus (Igarashi et al., 1996, 2000; Shiroza et al., 1998).

In a previous cross-sectional study, we reported that children harbouring both $S$. mutans and $S$. sobrinus had a significantly higher incidence of dental caries than those with S. mutans 
alone (Okada et al., 2002). However, there are few longitudinal studies of the relationship between these two species and caries activities in children (Hirose et al., 1993).

In the present study, we detected $S$. mutans and S. sobrinus using a PCR method in pre-school children, and then compared their presence with the incidence of dental caries over a 1-year period.

\section{METHODS}

Sixty Japanese pre-school children, all aged $3-5$ years and with primary dentition, who were visitors to the Hiroshima University Dental Hospital were enrolled in this study. Consent for participation was obtained from at least one of their parents prior to the study according to the ethical guidelines of the Declaration of Helsinki (1975). The subjects received a dental examination by two well-trained paediatric dentists (Y. S. and T. D.) while seated in a dental chair, using the WHO caries diagnostic criteria to determine the decayed, missing, filled teeth (dmft) index (WHO, 1987). Those who had received antibiotics within the previous 3 months or with systemic diseases were excluded. In a sample group of 20 subjects, the percentage agreement between the examining dentists was over $90 \%$ for inter-examiner reproducibility for dmft criteria.

Plaque sampling. Dental plaque was collected from all erupted teeth by brushing with a sterile toothbrush for $1 \mathrm{~min}$, using a previously described method (Okada et al., 2000). Plaque adhering to the toothbrush was removed by washing several times in a tube of sterile distilled water. The plaque samples were immediately transported to our research laboratory and stored at $-20^{\circ} \mathrm{C}$, prior to extraction of genomic DNA.

Genomic DNA preparation. S. mutans $\mathrm{JCM} 5175^{\mathrm{T}}$ and S. sobrinus ATCC2 $2607^{\mathrm{T}}$ were used as controls. PCR detection of the tested species was performed using primers described by Igarashi et al. $(1996,2000)$ while that of $16 \mathrm{~S}$ rDNA was done by the method of Goncharoff et al. (1993).

Plaque samples were first harvested by centrifugation at $1600 \mathrm{~g}$ for $20 \mathrm{~min}$. The supernatants were then discarded, and individual cell pellets were stored at $-20^{\circ} \mathrm{C}$ until DNA isolation. A genomic DNA preparation from each plaque sample was obtained using a standard miniprep procedure (Wilson, 1990), to which we added an RNase treatment (Smith et al., 1989). DNA concentrations in the dental plaque samples were calculated by measuring $A_{260}$ and the quality was estimated by the $A_{260} / A_{280}$ ratio (Sambrook et al., 1989).

PCR amplification. PCR amplification was performed in a reaction mixture $(25 \mu \mathrm{l})$ consisting of PCR beads (Amersham Pharmacia Biotech) that contained an enzyme, along with the required reagents,
25 pmol of each primer and 20-50 ng of template DNA solution in a thermal cycler (PC-700 program temperature control system; ASTEC). Each set of PCR analyses included a negative control (water blank) in addition to the positive control. The reaction mixture was denatured at $95^{\circ} \mathrm{C}$ for $3 \mathrm{~min}$, followed by 26 cycles of denaturation at $95^{\circ} \mathrm{C}$ for $1 \mathrm{~min}$, annealing at $55^{\circ} \mathrm{C}$ for $1 \mathrm{~min}$ and extension at $72{ }^{\circ} \mathrm{C}$ for $1 \mathrm{~min}$, with a final cycle of $94{ }^{\circ} \mathrm{C}$ for $1 \mathrm{~min}, 55^{\circ} \mathrm{C}$ for $1 \mathrm{~min}$ and $72{ }^{\circ} \mathrm{C}$ for $5 \mathrm{~min}$ (Igarashi et al., 2000). Following amplification, $15 \mu \mathrm{l}$ of the PCR products was analysed by electrophoresis on a $1.2 \%$ agarose gel. After staining with ethidium bromide, the newly synthesized DNA fragments were visualized under a $302 \mathrm{~nm}$ UV light. The size of the PCR products was estimated from the electrophoretic migration of products relative to a 100 bp ladder marker (Amersham Pharmacia Biotech).

Statistical analysis. A Mann-Whitney U-test was employed to compare caries scores between combinations of the bacteria, and a Wilcoxon rank test was used to compare caries scores between the baseline and after 1 year. A standard computer program was used for statistical analysis (Statview; Abacus Concepts).

\section{RESULTS}

At baseline the prevalences of $S$. mutans and $S$. sobrinus were $61.7 \%$ and $56.6 \%$, respectively. Thirteen $(21.7 \%)$ subjects were positive for $S$. mutans alone, $10(16.6 \%)$ for S. sobrinus alone and $24(40.0 \%)$ positive for both $S$. mutans and $S$. sobrinus, while $13(21.7 \%)$ were negative for both bacteria.

Table 1 shows the prevalence of previous caries experience and caries incremental increases in the children, and the combinations of the two bacteria detected in them. Twelve $(92 \cdot 3 \%)$ of the children with S. mutans alone and 23 (95.6\%) with both $S$. mutans and $S$. sobrinus had past caries experiences. Further, five $(38.5 \%)$ of the children with $S$. mutans alone, four $(40.0 \%)$ of those with $S$. sobrinus alone and $16(66.7 \%)$ of those with both S. mutans and S. sobrinus had caries incremental increases, while two (15.4\%) with neither $S$. mutans nor $S$. sobrinus also had an incremental increase.

Caries prevalences in children with $S$. mutans alone or in combination with $S$. sobrinus at baseline and after 1 year are shown in Table 2. The dmft scores of those positive for both organisms at baseline and after 1 year were significantly higher than of those positive for $S$. mutans alone at the same stages $(P<0.01$ and $P<0.001$, respectively). Further, $\mathrm{dmft}$ scores of subjects positive for both after 1 year were significantly higher than at baseline $(P<0.001)$, and the

Table 1. Children with previous caries experience at baseline and caries incremental increases after 1 year, and the combination of mutans streptococci detected

\begin{tabular}{|c|c|c|c|c|c|}
\hline \multicolumn{2}{|c|}{ Micro-organisms present } & \multicolumn{2}{|c|}{ Previous caries experience } & \multicolumn{2}{|c|}{ Caries incremental increase } \\
\hline S. mutans & S. sobrinus & No. & $\%$ & No. & $\%$ \\
\hline+ & - & 12 & $92 \cdot 3$ & 5 & $38 \cdot 5$ \\
\hline+ & + & 23 & $95 \cdot 6$ & 16 & $66 \cdot 7$ \\
\hline- & + & 5 & $50 \cdot 0$ & 4 & $40 \cdot 0$ \\
\hline- & - & 6 & $46 \cdot 2$ & 2 & $15 \cdot 4$ \\
\hline
\end{tabular}


Table 2. Caries prevalence in children with $S$. mutans alone or in combination with $S$. sobrinus at baseline and after 1 year

Statistical significance between groups: ${ }^{\star} P<0 \cdot 01,{ }^{* *} P<0 \cdot 001,{ }^{* *} P<0 \cdot 05$, Mann-Whitney $\mathrm{U}$ test; $\uparrow P<0 \cdot 001$, Wilcoxon rank test. Data for $\mathrm{dmft}$ scores are presented as mean (SD).

\begin{tabular}{|c|c|c|c|c|}
\hline \multirow{2}{*}{$\begin{array}{l}\text { Micro-organisms } \\
\text { present }\end{array}$} & \multirow{2}{*}{$\begin{array}{l}\text { No. at } \\
\text { baseline }\end{array}$} & \multicolumn{2}{|c|}{$\mathrm{dmft}$} & \multirow[t]{2}{*}{ Increase in $\mathrm{dmft}$} \\
\hline & & Baseline & After 1 year & \\
\hline S. mutans & 13 & $4.31(3.59)^{\star}$ & $4.85(3.83)^{\star *}$ & $0.54(0.78)^{\star * \star}$ \\
\hline S. mutans + S. sobrinus & 24 & $9.58(5.23)^{*} \dagger$ & $11.67(4.82)^{* * \dagger}$ & $2.08(2.03)^{* * *}$ \\
\hline
\end{tabular}

increase in $\mathrm{dmft}$ scores of subjects positive for both $S$. mutans and $S$. sobrinus was significantly greater than in those positive for $S$. mutans alone $(P<0 \cdot 05)$.

Table 3 shows PCR results obtained from the $11(18 \cdot 3 \%)$ children who were free from caries. Of these, two had only $S$. mutans and three had only $S$. sobrinus, while no children had both and six had neither detected.

\section{DISCUSSION}

Mutans streptococci transmission and colonization in the oral cavity are important factors for the prevention of dental caries. Usually the mother is regarded as the main source of the organisms found in children, based on chromosomal DNA-fingerprinting techniques used for the study of intrafamily clonal distribution (Alaluusua et al., 1994; Li \& Caufield, 1995; Saarela et al., 1996). Straetemans et al. (1998) suggested that a delayed acquisition of mutans streptococci may reduce the incidence of caries in both primary and permanent dentition later on. Further, acquisition of the organisms has been suggested to occur during a discrete age interval, termed the window of infectivity, between 19 and 31 months of age, during which the proportion of children with mutans streptococci was found to increase from $25 \%$ to $75 \%$ (Caufield et al., 1993; Köhler \& Andréen, 1994). Thus, it is of great importance to detect the presence of these organisms in early childhood for dental caries prediction and subsequent treatment, as S. mutans and $S$. sobrinus are regarded as the main initiator microorganisms of the disease, with lactobacilli and others participating in its progression. Further, the level of mutans streptococci in the oral cavity has been shown to have a correlation with both past caries experience and future caries activity (Köhler et al., 1981; Newbrun et al., 1984). The present results confirm that children with both S. mutans and $S$. sobrinus have a significantly higher caries incidence and incremental increase than those with $S$. mutans alone.

Our results suggested that the PCR method employed is suitable for investigating the intra-oral distribution of $S$. sobrinus as well as $S$. mutans, as the $16 \mathrm{~S}$ rDNA primers used confirmed the presence of bacteria in all plaque samples (data not shown). This tool provides a more sensitive means of detection of cariogenic bacterial species, as compared to conventional culture techniques (Ono et al., 1994; Igarashi et al., 1996, 2000).

The present findings showed that the prevalence of mutans streptococci in subjects 3-5 years old was $78 \cdot 3 \%$, which is in

Table 3. PCR results from children who were caries-free after 1 year

\begin{tabular}{|llcccc|}
\hline $\begin{array}{l}\text { Subject } \\
\text { no. }\end{array}$ & Sex & $\begin{array}{c}\text { Age at 1-year stage } \\
\text { (years, months) }\end{array}$ & \multicolumn{3}{c|}{ PCR result } \\
\cline { 3 - 6 } & & & S. mutans & S. sobrinus & rDNA $^{*}$ \\
\hline 1 & Male & 4,11 & - & - & + \\
2 & Male & 5,0 & - & + & + \\
3 & Female & 4,8 & + & - & + \\
4 & Female & 5,2 & - & - & + \\
5 & Female & 4,2 & - & - & + \\
6 & Male & 4,4 & + & - & + \\
7 & Male & 5,1 & - & - & + \\
8 & Female & 4,1 & - & + & + \\
9 & Male & 4,9 & - & + & + \\
10 & Male & 4,3 & - & - & + \\
11 & Female & 4,1 & - & - & + \\
\hline
\end{tabular}

${ }^{\star} 16$ S ribosomal DNA. 
agreement with other surveys of pre-school children (Köhler et al., 1988, 1995a; Li et al., 1994). The percentages of 3-5year-old children positive for $S$. mutans and $S$. sobrinus were $61.7 \%$ and $56.6 \%$, respectively, while $16.6 \%$ of all subjects had $S$. sobrinus only and $40.0 \%$ had both $S$. mutans and $S$. sobrinus. Köhler et al. (1988) reported that S. sobrinus was found in combination with $S$. mutans in nearly all 4-year-old pre-school children tested, except for two in whom $S$. sobrinus was the only species detected, although contradicting results have been found with other populations (Masuda et al., 1979; Köhler et al., 1995b). In addition, it has been reported that MSB inhibits the growth of S. sobrinus to a greater degree than that of $S$. mutans (Jordan, 1986; de Soet et al., 1990). The inconsistencies among those studies and ours could be due, in part, to the detection methods employed or ethnic backgrounds of the study subjects.

The present PCR findings confirmed that children with both $S$. mutans and $S$. sobrinus had a significant caries prevalence as compared to those with only $S$. mutans both at baseline and after 1 year, which agrees with the results of previous studies (Köhler et al., 1988; Hirose et al., 1993; Nie et al., 2002). In addition, approximately $70 \%$ of the children with both bacteria had incremental caries increases over the 1-year study period, whereas less than $40 \%$ of those with only one of the organisms demonstrated such incremental increases. Similar results were reported in the longitudinal studies by Hirose et al. (1993) and Straetemans et al. (1998). Hirose et al. (1993) suggested that the prevalence of $S$. sobrinus in saliva was more closely associated with future caries activity, especially with smooth-surface caries increment, than the prevalence of $S$. mutans. In addition, a caries incremental increase was seen in a maximum of $79 \%$ of the children in that study and the dmft index increase was approximately 2 . In our study, the caries incremental increase in children with both $S$. mutans and S. sobrinus was four times higher than in those with $S$. mutans alone, indicating that children with both bacteria have higher caries activities than those with only S. mutans.

In the present study, $11(11 \cdot 8 \%)$ of the 60 children were caries free for 1 year, of whom five $(45 \cdot 5 \%)$ had either $S$. mutans or $S$. sobrinus, while none had both bacterial species. As a result, it is strongly suggested that the presence of both $S$. mutans and S. sobrinus in pre-school children is associated with significantly higher caries incidence than S. mutans alone. However, since the subject population in the present study was limited, further studies are required.

In conclusion, the present longitudinal study results indicate that children harbouring both $S$. mutans and S. sobrinus have a significantly higher incidence of dental caries than those positive for $S$. mutans alone.

\section{ACKNOWLEDGEMENTS}

This work was supported in part by a grant-in-aid for scientific research from the Ministry of Education, Science, Sports and Culture of Japan 15791210.

\section{REFERENCES}

Alaluusua, S., Alaluusua, S. J., Karjalainen, J. \& 7 other authors (1994). The demonstration by ribotyping of the stability of oral Streptococcus mutans infection over 5 to 7 years in children. Arch Oral Biol 39, $467-471$.

Carlsson, P., Gandour, I. A., Olsson, B., Rickardsson, B. \& Abbas, K. (1987). High prevalence of mutans streptococci in a population with extremely low prevalence of dental caries. Oral Microbiol Immunol 2, $121-124$.

Caufield, P. W., Cutter, G. R. \& Dasanayake, A. P. (1993). Initial acquisition of mutans streptococci by infants: evidence for a discrete window of infectivity. J Dent Res 72, 37-45.

de Soet, J. J., van Dalen, P. J., Pavicic, M. J. A. M. P. \& de Graaff, J. (1990). Enumeration of mutans streptococci in clinical samples by using monoclonal antibodies. J Clin Microbiol 28, 2467-2472.

Fujiwara, T., Sasada, E., Mima, N. \& Ooshima, T. (1991). Caries prevalence and salivary mutans streptococci in 0-2-year-old children of Japan. Community Dent Oral Epidemiol 19, 151-154.

Goncharoff, P., Figurski, D. H., Stevens, R. H. \& Fine, D. H. (1993). Identification of Actinobacillus actinomycetemcomitans: polymerase chain reaction amplification of $l k t A$-specific sequences. Oral Microbiol Immunol 8, 105-110.

Hamada, S. \& Slade, H. D. (1980). Biology, immunology, and cariogenicity of Streptococcus mutans. Microbiol Rev 44, 331-384.

Hirose, H., Hirose, K., Isogai, E., Miura, H. \& Ueda, I. (1993). Close association between Streptococcus sobrinus in the saliva of young children and smooth-surface caries increment. Caries Res 27, 292-297.

Igarashi, T., Yamamoto, A. \& Goto, N. (1996). Direct detection of Streptococcus mutans in human dental plaque by polymerase chain reaction. Oral Microbiol Immunol 11, 294-298.

Igarashi, T., Yamamoto, A. \& Goto, N. (2000). PCR for detection and identification of Streptococcus sobrinus. J Med Microbiol 49, 1069-1074.

Jordan, H. V. (1986). Cultural methods for the identification and quantitation of Streptococcus mutans and lactobacilli in oral samples. Oral Microbiol Immunol 1, 23-30.

Köhler, B. \& Andréen, I. (1994). Influence of caries-preventive measures in mothers on cariogenic bacteria and caries experience in their children. Arch Oral Biol 39, 907-911.

Köhler, B., Pettersson, B. M. \& Bratthall, D. (1981). Streptococcus mutans in plaque and saliva and the development of caries. Scand J Dent Res 89, 19-25.

Köhler, B., Andréen, I. \& Jonsson, B. (1988). The earlier the colonization by mutans streptococci, the higher the caries prevalence at 4 years of age. Oral Microbiol Immunol 3, 14-17.

Köhler, B., Bjarnason, S., Care, R., Mackevica, I. \& Rence, I. (1995a). Mutans streptococci and dental caries prevalence in a group of Latvian preschool children. Eur J Oral Sci 103, 264-266.

Köhler, B., Bjarnason, S., Finnbogason, S. Y. \& Holbrook, W. P. (1995b). Mutans streptococci, lactobacilli and caries experience in 12year-old Icelandic urban children, 1984 and 1991. Community Dent Oral Epidemiol 23, 65-68.

Li, Y. \& Caufield, P. W. (1995). The fidelity of initial acquisition of mutans streptococci by infants from their mothers. J Dent Res 74, $681-685$.

Li, Y., Navia, J. M. \& Caufield, P. W. (1994). Colonization by mutans streptococci in the mouths of 3-and 4-year-old Chinese children with or without enamel hypoplasia. Arch Oral Biol 39, 1057-1062.

Loesche, W. J. (1986). Role of Streptococcus mutans in human dental decay. Microbiol Rev 50, 353-380. 
Masuda, N., Tsutsumi, N., Sobue, S. \& Hamada, S. (1979). Longitudinal survey of the distribution of various serotypes of Streptococcus mutans in infants. J Clin Microbiol 10, 497-502.

Newbrun, E., Matsukubo, T., Hoover, C. I., Graves, R. C., Brown, A. T., Disney, A. J. \& Bohannan, H. M. (1984). Comparison of two screening tests for Streptococcus mutans and evaluation of their suitability for mass screenings and private practice. Community Dent Oral Epidemiol 12, 325-331.

Nie, M., Fan, M. \& Bian, K. (2002). Transmission of mutans streptococci in adults within a Chinese population. Caries Res 36, 161-166.

Okada, M., Hayashi, F. \& Nagasaka, N. (2000). Detection of Actinobacillus actinomycetemcomitans and Porphyromonas gingivalis in dental plaque samples from children 2 to 12 years of age. J Clin Periodontol 27, $763-768$

Okada, M., Soda, Y., Hayashi, F., Doi, T., Suzuki, J., Miura, K. \& Kozai, K. (2002). PCR detection of Streptococcus mutans and S. sobrinus in dental plaque samples from Japanese pre-school children. J Med Microbiol 51, 443-447.

Ono, T., Hirota, K., Nemoto, K., Fernandez, E. J., Ota, F. \& Fukui, K. (1994). Detection of Streptococcus mutans by PCR amplification of spaP gene. J Med Microbiol 41, 231-235.

Saarela, M., Hannula, J., Mättö, J., Asikainen, S. \& Alaluusua, S. (1996). Typing of mutans streptococci by arbitrarily primed polymerase chain reaction. Arch Oral Biol 41, 821-826.

Sambrook, J., Fritsch, E. F. \& Maniatis, T. (1989). Molecular Cloning: a Laboratory Manual, 2nd edn. Cold Spring Harbor, NY: Cold Spring Harbor Laboratory.
Shiroza, T., Shinozaki, N., Watanabe, T., Ikemi, T., Fukushima, K. \& Abiko, Y. (1998). Rapid isolation of chromosomal DNA from oral streptococci and polymerase chain reaction-oriented restriction fragment-length polymorphism analysis for genetic heterogeneity. Oral Microbiol Immunol 13, 11-16.

Smith, G. L., Socransky, S. S., Smith, C. M., Scully, C. \& Gilmour, G. (1989). Rapid method for the purification of DNA from subgingival microorganisms. Oral Microbiol Immunol 4, 47-51.

Straetemans, M. M. E., van Loveren, C., de Soet, J. J., de Graaff, J. \& ten Cate, J. (1998). Colonization with mutans streptococci and lactobacilli and the caries experience of children after the age of five. $J$ Dent Res 77, 1851-1855.

Svanberg, M. \& Krasse, B. (1990). Comparative recovery of mutans streptococci on two selective media. Caries Res 24, 36-38.

Wade, W. G., Aldred, M. J. \& Walker, D. M. (1986). An improved medium for isolation of Streptococcus mutans. J Med Microbiol 22, 319-323.

Whiley, R. A. \& Beighton, D. (1998). Current classification of the oral streptococci. Oral Microbiol Immunol 13, 195-216.

WHO (1987). Individual tooth status and treatment need. In Oral Health Surveys: Basic Methods, 3rd edn, pp. 34-39. Geneva: World Health Organization.

Wilson, K. (1990). Preparation of genomic DNA from bacteria. In Current Protocols in Molecular Biology, 2.4.1-2.4.2.4.2. Edited by F. M. Ausubel and others. Philadelphia: Wiley Interscience. 